\title{
Diálogos entre desenhos teóricos e contornos práticos III Simpósio Internacional de Terapia Ocupacional Social
}

\begin{abstract}
Abrimos este número dos Cadernos de Terapia Ocupacional da Universidade Federal de São Carlos (UFSCar) com a satisfação de compartilhar alguns dos acontecimentos do III Simpósio Internacional de Terapia Ocupacional Social - III SITOS, realizado nos dias 27 e 28 de abril de 2016, no campus São Carlos da UFSCar, apresentando, como tema central, os "Desenhos teóricos e contornos práticos" desta subárea, no intuito de promover um espaço para o diálogo acerca de construções teóricas e proposiçôes da atuação terapêutica-ocupacional social.

Com a organização de parte da equipe do Laboratório METUIA/UFSCar e com o apoio da RENETO - Rede Nacional de Ensino em Terapia Ocupacional, o evento contou com a participaçáo de estudantes de graduação e pós-graduação, além de profissionais e docentes da área, de diversas regiōes do Brasil, bem como com participantes dos países Argentina, Chile e Canadá, que, motivados pela temática, puderam compartilhar suas experiências.
\end{abstract}

Em poucas palavras, o Simpósio voltou sua temática para a questáo social na contemporaneidade, apresentando como mote, fundamentalmente, o papel do terapeuta ocupacional na mediação pela garantia dos direitos advindos da cidadania. Sob estas perspectivas, o Brasil desenvolveu importantes experiências e conhecimentos, envolvendo profissionais, docentes, discentes e pesquisadores nesse desafio, nos últimos 30 anos, formulando construções teóricas e metodológicas para a terapia ocupacional social.

Sob esse enquadre, o III SITOS pontuou a tarefa da discussão da questão e do contexto social para os terapeutas ocupacionais, de modo geral, e o debate em torno das proposiçóes do que foi se denominando como Terapia Ocupacional Social no Brasil. Dentre as atividades do encontro, a palestra de Elizabeth A. Townsend ${ }^{1}$, professora emérita da Dalhousie University, do Canadá, mundialmente reconhecida na Terapia Ocupacional, em diversos âmbitos, apresentou os contornos internacionais da discussão social por meio da justiça ocupacional, conceito ao qual dedicou grande parte seus estudos. A Professora Elizabeth A. Townsend pontuou, elogiosamente, a construção feita em torno da temática no Brasil, propondo a realização de uma ponte para a ampla divulgação científica acerca de nossas experiências.

O evento contou com mesas e discussôes acerca dos conceitos teóricos da terapia ocupacional social e espaços para discussão das práticas no campo social em Grupos de Trabalhos (GTs) e na apresentação dos quatro núcleos do projeto METUIA: Universidade Federal de São Carlos (UFSCar), Universidade de São Paulo (USP), Universidade Federal de São Paulo (UNIFESP) e Universidade Federal do Espírito Santo (UFES).

Além dos debates, o evento também contou com um marco acadêmico comemorativo importante: o lançamento do livro Terapia Ocupacional Social: Desenhos Teóricos e Contornos Práticos, pela EdUFSCar, organizado pelas Professoras Roseli Esquerdo Lopes e Ana Paula S. Malfitano, com apoio da FAPESP e da RENETO. O livro traz reflexóes realizadas por pesquisadores e técnicos da área, em duas seçôes, sendo a primeira dedicada às principais discussóes teóricas em torno da terapia ocupacional social e a segunda, a reflexôes advindas de experiências práticas. Trata-se de uma produção coletiva, com a participação de 25 autores, sendo 20 deles atuais docentes em sete importantes universidades públicas do País. Ressalta-se o valor atribuído a esta obra tanto pelas contribuições no nível de conteúdos como também pela concretização do que se vem construindo e propondo na terapia ocupacional social brasileira.

Destacam-se, como principais encaminhamentos, a criaçáo de um Grupo de Trabalho junto à RENETO, com o intuito de se discutir o ensino e a formação profissional no âmbito da terapia ocupacional social, e a elaboração de um manifesto em defesa do estado democrático de direito. Este manifesto vincula-se à atual crise política brasileira, convocando os terapeutas ocupacionais, a partir de nosso compromisso 
ético e político, para a defesa da democracia no nosso país, fruto de intensa luta e mobilizações sociais, nas quais muitos de nós estivemos e/ou estamos diretamente implicados.

Convidamos os leitores a refletir sobre os temas propostos e discutidos no evento, e sua importância para a construção de uma terapia ocupacional que, como ficou explicitado no evento, se faz essencialmente brasileira ou, como intitulam alguns, "do sul”. Mostra-se também válido refletir acerca de suas possibilidades de contribuição para a terapia ocupacional que se faz em outros territórios e realidades. Nosso desejo é que o acúmulo que temos conseguido nacionalmente em torno da proposição de reflexóes e açóes terapêutico-ocupacionais seja parte das iniciativas para o fortalecimento de nosso campo profissional no cenário mundial.

Boa leitura a todos!

\section{Livia Celegati Pan, Marina Jorge Silva, Rafael Garcia Barreiro}

Comissão Organizadora do III Simpósio Internacional de Terapia Ocupacional Social²

Departamento de Terapia Ocupacional, Universidade Federal de São Carlos - UFSCar, São Carlos, SP, Brasil.

\footnotetext{
1 Agradecemos à Fundação de Amparo à Pesquisa do Estado de São Paulo - FAPESP e ao Programa de Pós-Graduação em Terapia Ocupacional da UFSCar pelo apoio para a viabilização da presença da Professora Doutora Elizabeth Townsend no III SITOS.

2 Agradecemos a todo(a)s colegas que nos ajudaram na realização do III SITOS, nos apoiando das mais variadas formas, especialmente às professoras Patrícia Leme de Oliveira Borba (UNIFESP); Lilian Vieira Magalhães (UFSCar), e Sandra Maria Galheigo (USP), por todo auxílio na tradução e na viabilização da comunicação; aos alunos de pós-graduação e graduação: Pamela Cristina Bianchi; Stéphany Conceição Correia Alves Guedes; Rodrigo Alves dos Santos Silva; Paula Marcondes Schmidt Hebbel; Tatiana de Vasconcellos Melo; Maria Aparecida Pinheiro, e Gabriela Agnelli Martinez, bem como à ADUFSCar/Sindicato - Sindicato dos Docentes em Instituiçóes Federais de Ensino Superior dos Municípios de São Carlos, Araras e Sorocaba, e ao Departamento de Terapia Ocupacional da UFSCar.
} 